\title{
PENGARUH KEPUASAN PENGELOLAAN SUMBER DAYA MANUSIA TERHADAP KINERJA DAN LOYALITAS DOSEN DAN TENAGA KEPENDIDIKAN IAIN PADANGSIDIMPUAN
}

\author{
Asnah \\ (Dosen Fakultas Tarbiyah dan Ilmu Keguruan IAIN Padangsidimpuan) \\ Email: asnahray@gmail.com
}

\begin{abstract}
The problems of this research come from many aspects; one of them is from human resources, it is about managerial system, discipline, responsibility, quality, motivation, and spirit to work. This research is aimed to know the level of satisfaction, performance, and loyalty of the lecturers and educators. It is also to examine the effectiveness of organizing the human resources satisfaction to the performance and loyalty in IAIN Padangsidimpuan. Quantitative research has been done in this research in the type of correlational by giving questionnaires as the instrument which is given to 74 sample of this research. The data have been analysed by using simple regression. Then, the data shown that the range of satisfaction to the human sources management is about $52.70 \%$ with mean score of the satisfaction is 52.7973 , it is in the level of enough or medium. The range of performance is also in the level enough or medium, it is for $81.08 \%$ or in mean score is 78.9865 ; meanwhile the loyalty is on the high category, it is for $83.78 \%$ with the mean score is 76.06135 . To test the hypothesis, it is done by using simple regression. The result of the regression from the first hypothesis is 0.291, and hypothesis is accepted. It means that the satisfaction of human resources management has positive effects to the lecturer's and educators' performance. Then, the second hypothesis is also accepted, because the coefficient correlation between the satisfaction of human resources management and the lecturers' and educators' loyalty is 0.282. Both hypothesis in this research are accepted based on the result of regression.
\end{abstract}

Keywords: the satisfaction, human resources management, loyalty, lecturers and educators.

\section{Abstrak}

IAIN Padangsidimpuan masih dihadapkan pada beberapa problem kinerja SDM, seperti belum berjalannya sistem manajerial, disiplin 
kerja, tanggung jawab kerja, kualitas kerja, motivasi kerja, semangat dalam melaksanakan tugasnya. Problem ini muncul ke permukaan tidak berdiri sendiri, melainkan ada korelasinya dengan ketidakpuasan terhadap situasi dan kondisi kerja yang dihadapi dan sikapnya terhadap pekerjaan dan kondisi kerjanya. Atas dasar permasalahan di atas, penelitian ini bertujuan mengetahui tingkat kepuasan, kinerja dan loyalitas dosen dan tenaga kependidikan serta menemukan besaran pengaruh kepuasan pengelolaan sumber daya manusia terhadap kinerja dan loyalitas dosen dan tenaga kependidikan IAIN Padangsidimpuan. Metode yang digunakan dalam penelitian ini adalah metode korelasi dengan pendekatan kuantitatif. Untuk mengukur kepuasan dosen dan tenaga kependidikan, peneliti menggunakan kuisioner yang ditujukan kepada dosen dan tenaga kependidikan IAIN Padangsidimpuan sebanyak 74 orang (48 dosen dan 26 tenaga kependidikan) sebagai sampel. Kemudian dinalisis dengan menggunakan rumus regresi sederhana. Berdasarkan data yang diperoleh dapat diambil kesimpulan bahwa tingkat kepuasan dosen dan tenaga kependidikan IAIN Padangsidimpuan terhadap pengelolaan SDM berada pada kategori cukup/sedang dengan indeks sebesar 52,70\%, nilai rata-rata kepuasan sebesar 52,7973. Hal ini sejalan dengan tingkat kinerja $81,08 \%$ (kategori cukup/sedang), dengan nilai rata-rata kinerja sebesar 78,9865. Sementara tingkat loyalitas berada pada kategori tinggi yaitu $83,78 \%$, dengan nilai rata-rata loyalitas sebesar 76,0135. Selanjutnya dilakukan uji hipotesis dengan menggunakan regresi, hasil uji regresi ditemukan angka koefisien korelasi sebesar 0,291. Angka ini membuktikan hipotesis pertama yang menyatakan; kepuasan pengelolaan SDM berpengaruh positif terhadap kinerja dosen dan tenaga kependidikan IAIN Padangsidimpuan, diterima. Begitu pula dengan hipotesis kedua angka koefisien korelasinya sebesar 0,282. Berdasarkan perhitungan regresi tersebut dinyatakan bahwa hipotesis kedua yang menyatakan; kepuasan pengelolaan SDM berpengaruh positif terhadap loyalitas dosen dan tenaga kependidikan IAIN Padangsidimpuan, diterima.

Kata Kunci: kepuasan, pengelolaan SDM, loyalitas, dosen, dan tenaga kependidikan.

\section{PENDAHULUAN}

Banyaknya keluhan-keluhan yang disampaikan terkait dengan mutu kinerja dosen dan pegawai mencerminkan bahwa kinerja dosen dan pegawai masih belum sesuai dengan harapan stackholders. Hal ini diduga tidak terlepas 
dari faktor-faktor seperti kepuasan kerja, motivasi dan disiplin kerja pegawai itu sendiri di dalam melaksanakan pekerjaannya.

Berdasarkan hasil monitoring terhadap kinerja SDM yang dilakukan tim monitoring pada tgl 15 sampai dengan 17 Desember 2014, IAIN Padangsidimpuan masih dihadapkan pada beberapa problem kinerja SDM, seperti belum berjalannya sistem manajerial, disiplin kerja, tanggung jawab kerja, kualitas kerja, motivasi kerja, semangat dalam melaksanakan tugasnya, kehadiran mengajar, pelayanan kepada mahasiswa kurang maksimal. Sebenarnya persoalan yang dihadapi IAIN Padangsidimpuan tidak hanya masalah SDM tetapi juga dari sarana dan prasarana pendidikan masih belum memenuhi standar.

Dari berbagai masalah yang teridentifikasi di atas, peneliti mencoba menyimpulkan sementara bahwa kinerja dan loyalitas dosen dan tenaga kependidikan IAIN Padangsidimpuan belum maksimal. Apa sebenarnya yang membuat dosen dan tenaga kependidikan belum bekerja secara maksimal, penuh semangat dan penuh gairah? Problem ini muncul ke permukaan tidak berdiri sendiri, melainkan ada korelasinya dengan ketidakpuasan terhadap situasi dan kondisi kerja yang dihadapi dan sikapnya terhadap pekerjaan dan kondisi kerjanya.

Menurut Lowler, sebagaimana dikemukakan oleh Fieldman dan Arnold, sumber-sumber kepuasan kerja seseorang adalah: gaji, kerja itu sendiri, supervisi, promosi, kerja sama antar pekerja dan kondisi kerja. ${ }^{1}$

Atas dasar pertimbangan di atas, peneliti merasa tertarik untuk menelusuri lebih jauh persoalan komitmen dan kinerja dikaitkan dengan situasi dan kondisi tempat dosen dan tenaga kependidikan ini bekerja. Namun untuk terpokusnya penelitian ini peneliti membatasinya dalam sebuah judul: "Pengaruh Kepuasan Pengelolaan Sumber Daya Manusia Terhadap Kinerja dan Loyalitas Dosen dan Tenaga Kependidikan IAIN Padangsidimpuan".

Adapun tujuan yang ingin dicapai dalam penelitian ini adalah untuk menjelaskan besaran pengaruh kepuasan pengelolaan sumber daya manusia terhadap kinerja dan loyalitas dosen dan tenaga kependidikan IAIN Padangsidimpuan.

${ }^{1}$ Daniel C Fieldman dan Arnold, Managing Individual and Group Behavior in Education (Singapore: Mc Graw Hill Book Co., 2013), hlm. 25. 
34 | TAZKIR: Jurnal Penelitian Ilmu-ilmu Sosial dan Keislaman

Vol. 03 No. 1 Juni 2017

\section{KAJIAN TEORTIS}

\section{Teori Kepuasan}

Wexley dan Yulk dalam bukunya yang berjudul Organizational Behaviour And Personnel Psycology mengungkapkan teori-teori tentang kepuasan kerja. Ada tiga macam teori yang lazim dikenal, yaitu:

\section{1) Discrepancy Theory (Teori Kesenjangan)}

Teori ini pertama kali dipelopori oleh Porter. Porter mengukur kepuasan kerja seseorang dengan menghitung selisih antara apa yang seharusnya dengan kenyataan yang dirasakan (difference between how much of something there should be and how much there "is now"). ${ }^{2}$

Teori ini dikembangkan oleh Locke yang menyatakan bahwa kepuasan kerja seseorang tergantung pada selisih (discrepancy) antara harapan, kebutuhan atau nilai yang seharusnya dengan apa yang menurut perasaannya telah dicapai melalui pekerjaan. ${ }^{3}$ Dengan demikian, bila tidak ada selisih antara harapan dengan kenyataan, maka orang akan merasa puas. Bila yang didapat lebih besar dari yang diharapkan, maka orang tersebut merasa lebih puas lagi. Ini merupakan selisih positif. Di lain pihak, bila kenyataan berada dibawah standar minimum harapan, maka akan terjadi ketidakpuasan. Ini merupakan selisih negatif.

\section{2) Equity Theory (Teori Keadilan)}

Teori ini dikembangkan oleh Adams. Prinsip pada teori ini adalah bahwa orang akan merasa puas atau tidak puas, tergantung apakah ia merasakan adanya equity (keadilan) atau tidak pada suatu situasi. Perasaan adil atau tidak adil (equity and inequity) atas suatu situasi, diperoleh dengan cara membandingkan dirinya dengan orang lain yang sekelas, sekantor maupun di tempat lain. Adams dalam Usmara menyatakan dalam versinya tentang teori keadilan bahwa kepuasanditentukan oleh keseimbangan input-outcome yang dirasakan seseorang. ${ }^{4}$

\section{3) Two Factors Theory}

Prinsip dari teori ini adalah bahwa kepuasan dan ketidakpuasan kerja merupakan dua hal yang berbeda. Menurut teori ini, karakteristik pekerjaan hlm. 109.

${ }^{2}$ Lyman W. Porter, Managerial Attitudes and Performance (Texas: Business Publication, 1996), ${ }^{3}$ A. Usmara, Motivasi Kerja: Proses, Teori dan Praktik (Yogyakarta: Amara Books, 2006), hlm. ${ }^{4}$ Ibid., hlm. 102. 
dapat dikelompokkan menjadi dua kategori, yang satu dinamakan Dissatisfier atau hygiene factors dan yang lain dinamakan satisfier atau motivators.

Lebih jauh Herzberg mengklasifikasikan teorinya sebagai berikut: Motivator factor berhubungan dengan aspek-aspek yang terkandung dalam pekerjaan itu sendiri. Jadi berhubungan dengan job content atau disebut juga sebagai aspek intrinsik dalam pekerjaan. Faktor-faktor yang termasuk di sini adalah:

1) Achievement (keberhasilan menyelesaikan tugas).

2) Recognition (penghargaan).

3) Work it self (pekerjaan itu sendiri ).

4) Responsibility (tanggung jawab).

5) Possibility of growth (kemungkinan untuk mengembangkan diri).

6) Advancement (kesempatan untuk maju). ${ }^{5}$

Sementara itu Hygiene factor menurutnya adalah faktor yang berada di sekitar pelaksanaan pekerjaan; berhubungan dengan job context atau aspek ekstrinsik pekerja. faktor-faktor yang termasuk di sini adalah:

1) Working condition (kondisi kerja).

2) Interpersonal relation (hubungan antar pribadi).

3) Company policy and administration (kebijaksanaan perusahaan dan pelaksanaannya).

4) Supervision technical (teknik pengawasan).

5) Job security (perasaan aman dalam bekerja). ${ }^{6}$

Manusia pada dasarnya selalu berupaya untuk memenuhi kebutuhan hidupnya dengan berbagai cara, di antaranya dengan bekerja. Seseorang akan memberikan sumbangan tenaga dan pikirannya secara optimal kepada lembaga/organisasi tempat dia bekerja, apabila lembaga tersebut dapat memberikan kepuasan secara fisik dan psikhis.

Oleh karena itu suatu lembaga akan dapat mempertahankan sumber daya manusianya bila mereka merasa terpelihara dan memperoleh ganjaran sesuai dengan kepuasan lahiriah dan batiniahnya. Sebaliknya jika mereka merasa tidak terpelihara dan merasa tidak memperoleh ganjaran atau imbalan yang wajar, akan mudah tergoda dengan keadaan di luar tempat kerja. ${ }^{7}$

\footnotetext{
${ }^{5}$ Moh. As'ad, Psikologi Industri (Yogyakarta: liberty, 2004), hlm. 104-105.

${ }^{6}$ Ibid., hlm. 106-108.

${ }^{7}$ Sedarmayanti, Sumber Daya Manusia dan Produktivitas Kerja (Bandung: Mandar Maju, 2001),
} hlm. 17 . 
36 | TAZKIR: Jurnal Penelitian Ilmu-ilmu Sosial dan Keislaman

Vol.03 No. 1 Juni 2017

\section{METODE PENELITIAN}

Kegiatan penelitian ini dilaksanakan di IAIN Padangsidimpuan, di tempat peneliti bertugas sebagai dosen. Waktu penelitian dilakukan sejak bulan Maret 2015 s/d Oktober 2015, dengan melakukan berbagai tahapan mulai dari melakukan identifikasi dan membuat formulasi masalah, menyusun proposal/perencanaan, mengumpulkan data, menganalisis data sampai dengan membuat laporan. Populasi yang digunakan dalam penelitian ini adalah dosen dan tenaga kependidikan IAIN Padangsidimpuan dengan total populasi adalah 148 orang yang terbagi dalam kategori Dosen tetap (PNS) berjumlah 96 orang dan Tenaga Kependidikan (PNS) berjumlah 52 orang. Pengambilan sampel dilakukan secara rambang atau random, dimana masing-masing karakter diambil $50 \%$ sebagai perwakilan sehingga diperoleh sampel berjumlah 74 orang, terdiri atas 48 dosen dan 26 tenaga kependidikan.

Untuk mengukur tingkat kepuasan dosen dan tenaga kependidikan, serta kinerja dan variabel loyalitas peneliti menggunakan alat pengumpul data angket/kuesioner. Dalam penelitian ini angket yang digunakan adalah angket model skala likert, dengan rentangan skala empat. Pengujian validitas pada penelitian ini dilakukan dengan menggunakan anates. Hasil uji validitas tersebut menunjukkan bahwa variabel kepuasan memiliki nilai korelasi 0,97 variabel kinerja dosen 0,94 kinerja tenaga kependidikan 0,97 dan variabel loyalitas 0,97 lebih besar dari $r_{\text {tabel }}$ 0,374, sehingga dinyatakan seluruh variabel penelitian adalah valid. Selanjutnya hasil uji reliabilitas variabel kepuasan memiliki reliabilitas tes sebesar 0,99 variabel kinerja dosen dan tenaga kependidikan 0,97 dan variabel loyalitas 0,98. Untuk menemukan jawaban digunakan analisis statistik inferensial dengan rumus Product Moment dan dilanjutkan Regresi Ganda. Dalam melakukan analisis ini peneliti menggunakan alat bantu SPSS versi 20.

\section{HASIL PENELITIAN DAN PEMBAHASAN}

Tingkat Kepuasan Dosen dan Tenaga Kependidikan Terhadap Pengelolaan Sumber Daya Manusia

Data tingkat kepuasan terhadap pengelolaan sumber daya manusia dapat dilihat dalam tabel di bawah ini. 
Tabel 1

Persentase Kepuasan Dosen dan Tenaga Kependidikan

\begin{tabular}{|c|c|c|c|}
\hline \multirow{2}{*}{ Responden } & \multicolumn{3}{|c|}{ Frekuensi Kepuasan } \\
\cline { 2 - 4 } & Tinggi (\%) & Sedang (\%) & Rendah (\%) \\
\hline Dosen & 2 & 24 & 22 \\
& $(4,17 \%)$ & $(50 \%)$ & $(45,83 \%)$ \\
\hline Tenaga Kependidikan & 1 & 15 & 10 \\
& $(3,85 \%)$ & $(57,69 \%)$ & $(38,46 \%)$ \\
\hline TOTAL & $\mathbf{3}$ & $\mathbf{3 9}$ & $\mathbf{3 2}$ \\
& $\mathbf{( 4 , 0 6 \% )}$ & $\mathbf{( 5 2 , 7 0 \% )}$ & $\mathbf{( 4 3 , 2 4 \% )}$ \\
\hline
\end{tabular}

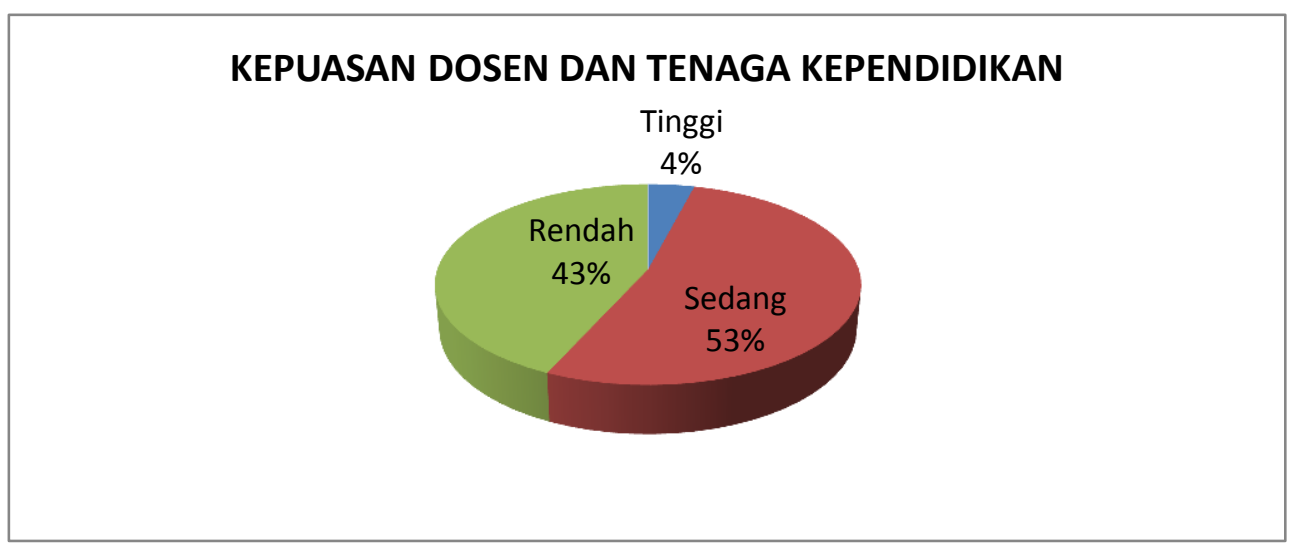

\section{Gambar 1}

\section{Diagram Serabi Variabel Kepuasan Dosen dan Tenaga Kependidikan}

Berdasarkan tabel 2 di atas, dilihat dari 48 orang dosen yang menjadi responden penelitian ini, dapat diketahui bahwa rata-rata tingkat kepuasan terhadap pengelolaan SDM, berada pada kategori sedang (50\%), demikian juga untuk tenaga kependidikan rata-rata berada pada kategori sedang (57,69\%). Dilihat secara keseluruhan tingkat kepuasan dosen dan tenaga kependidikan terhadap pengelolaan SDM berada pada kategori sedang (mean dengan interval 51 - 70) sebanyak 52,70\%. Jika dibandingkan dengan hasil perhitungan SPSS diperoleh mean kepuasan sebesar 52,7973.

\section{Tingkat Kinerja Dosen dan Tenaga Kependidikan}

Data tentang kinerja dosen dan tenaga kependidikan dapat dilihat pada tabel berikut: 
38 | TAZKIR: Jurnal Penelitian Ilmu-ilmu Sosial dan Keislaman

Vol.03 No. 1 Juni 2017

Tabel. 2

Persentase Kinerja Dosen dan Tenaga Kependidikan

\begin{tabular}{|c|c|c|c|}
\hline \multicolumn{1}{|c|}{ Responden } & \multicolumn{3}{|c|}{ Frekuensi Kinerja } \\
\hline & $\begin{array}{c}\text { Tinggi } \\
\mathbf{( \% )}\end{array}$ & $\begin{array}{c}\text { Sedang } \\
\mathbf{( \% )}\end{array}$ & $\begin{array}{c}\text { Rendah } \\
\mathbf{( \% )}\end{array}$ \\
\hline Dosen & - & 43 & 5 \\
$(89,58 \%)$ & $(10,42 \%)$ \\
\hline Tenaga Kependidikan & 9 & 17 & - \\
\hline TOTAL & $(34,62 \%)$ & $(65,38 \%)$ & $\mathbf{6}$ \\
& $\mathbf{9}$ & $\mathbf{6 0}$ & $\mathbf{( 1 2 , 1 6 \% )}$ \\
\hline
\end{tabular}

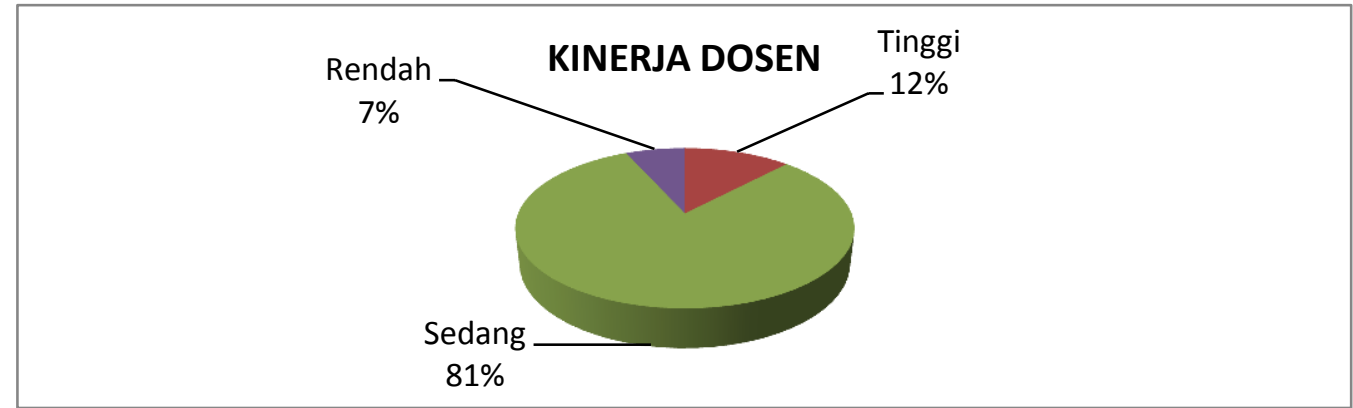

Gambar 2

Diagram Serabi Variabel Kinerja Dosen

Tabel 2 di atas menggambarkan bahwa persentasi rata-rata tingkat kinerja dosen, berada pada kategori sedang (89,58\%), demikian juga untuk tenaga kependidikan persentase rata-rata berada pada kategori sedang $(65,38 \%)$. Dilihat secara keseluruhan tingkat kinerja dosen dan tenaga kependidikan berada pada kategori sedang (mean dengan interval 69 - 96 dan mean dengan interval 59 -82) sebanyak $81,08 \%$. Jika dibandingkan dengan hasil perhitungan SPSS diperoleh mean kinerja sebesar 78,9865 (lihat lampiran 3).

Rata-rata tingkat kinerja dosen dalam setiap aspeknya, seperti dijelaskan pada tabel berikut:

Tabel 3

Rata-rata Kinerja Dosen Pada Setiap Aspek

\begin{tabular}{|l|r|r|r|}
\hline & $\begin{array}{c}\text { Pendidikan dan } \\
\text { Pengajaran }\end{array}$ & $\begin{array}{c}\text { Penelitian dan } \\
\text { Pengembangan } \\
\text { Ilmu }\end{array}$ & \multicolumn{2}{|c|}{$\begin{array}{c}\text { Pengabdian } \\
\text { Kepada } \\
\text { Masyarakat }\end{array}$} \\
\hline N $\begin{array}{l}\text { Valid } \\
\quad \begin{array}{l}\text { Missin } \\
\text { g }\end{array}\end{array} \quad 08$ & 48 & 48 \\
\end{tabular}




\begin{tabular}{|l|r|r|r|}
\hline & $\begin{array}{c}\text { Pendidikan dan } \\
\text { Pengajaran }\end{array}$ & $\begin{array}{c}\text { Penelitian dan } \\
\text { Pengembangan } \\
\text { Ilmu }\end{array}$ & $\begin{array}{c}\text { Pengabdian } \\
\text { Kepada } \\
\text { Masyarakat }\end{array}$ \\
\hline Mean & 34,7708 & 24,8750 & 19,2500 \\
Range & 18,00 & 16,00 & 15,00 \\
Minimum & 26,00 & 18,00 & 13,00 \\
Maximum & 44,00 & 34,00 & 28,00 \\
\hline
\end{tabular}

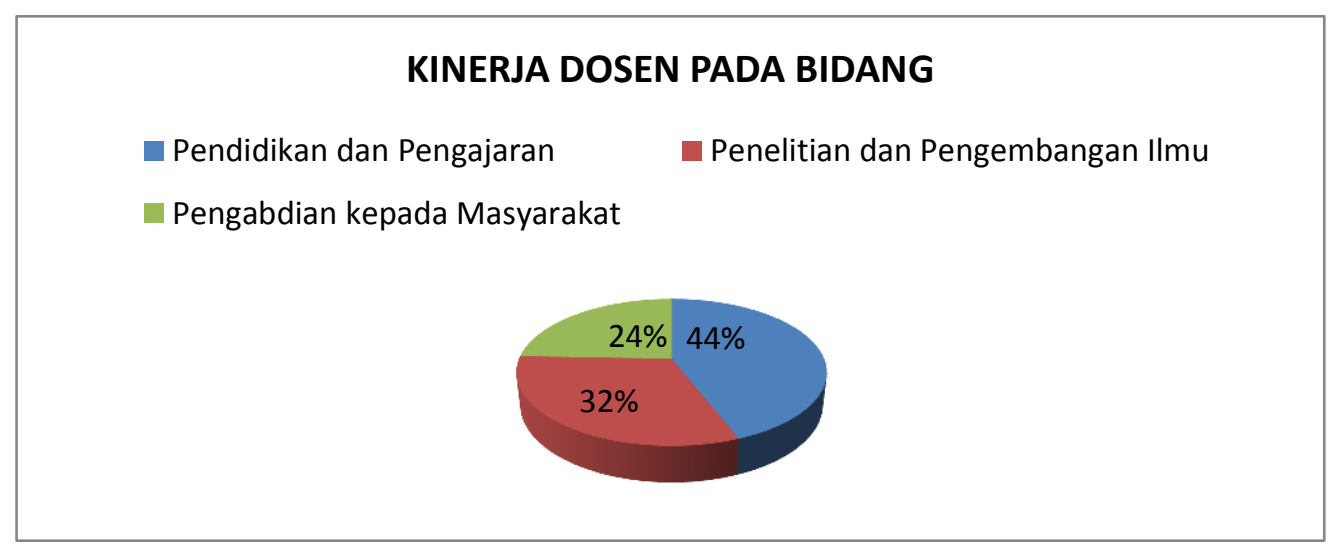

Gambar 3

Diagram Serabi Variabel Kinerja Dosen pada 3 Bidang

Sementara, rata-rata tingkat kinerja tenaga kependidikan dalam setiap aspeknya, seperti dijelaskan pada tabel berikut:

Tabel 4

Rata-rata Kinerja Tenaga Kependidikan Pada Setiap Aspek

\begin{tabular}{|c|c|c|c|c|c|c|}
\hline & & Kualitas & Kuantitas & $\begin{array}{c}\text { Ketepatan } \\
\text { Waktu }\end{array}$ & $\begin{array}{c}\text { Efektifit } \\
\text { as }\end{array}$ & $\begin{array}{c}\text { Kemandiri } \\
\text { an }\end{array}$ \\
\hline \multirow[t]{2}{*}{$\mathrm{N}$} & Valid & 26 & 26 & 26 & 26 & 26 \\
\hline & Missing & 22 & 22 & 22 & 22 & 22 \\
\hline \multicolumn{2}{|c|}{ Mean } & 34,6154 & 10,7308 & 10,8462 & 11,0385 & 11,9231 \\
\hline \multicolumn{2}{|c|}{ Range } & 20,00 & 6,00 & 6,00 & 8,00 & 6,00 \\
\hline \multicolumn{2}{|c|}{ Minimum } & 24,00 & 8,00 & 9,00 & 7,00 & 9,00 \\
\hline \multicolumn{2}{|c|}{ Maximum } & 44,00 & 14,00 & 15,00 & 15,00 & 15,00 \\
\hline
\end{tabular}


40 | TAZKIR: Jurnal Penelitian Ilmu-ilmu Sosial dan Keislaman

Vol.03 No. 1 Juni 2017

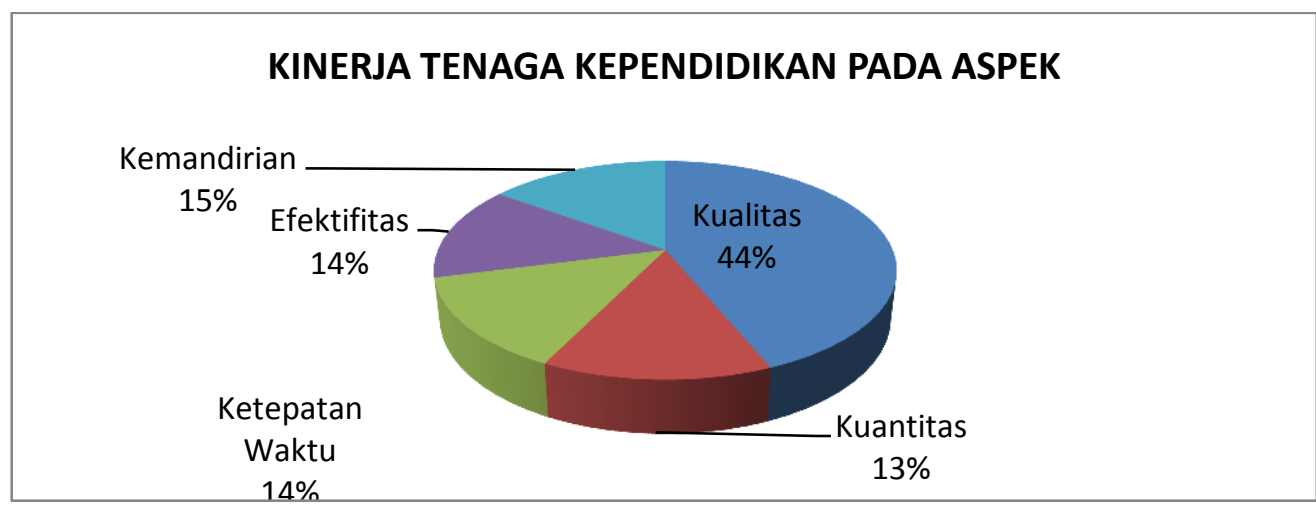

Gambar 4

\section{Diagram Serabi Variabel Kinerja Tenaga Kependidikan pada 5 Aspek}

Data di atas menggambarkan bahwa kinerja dosen lebih tinggi di bidang pendidikan dan pengajaran dibandingkan dengan bidang penelitian dan pengabdian kepada masyarakat. Berdasarkan skor ideal angket bidang penelitian dan pengembangan ilmu, maka data yang diperoleh menunjukkan bahwa bidang penelitian masih rendah terutama pada kegiatan penulisan buku, menerjemah dan menyunting karya ilmiah serta menjadi pembicara seminar baik di dalam maupun di luar kampus. Demikian juga dengan bidang pengabdian kepada masyarakat, masih banyak dosen yang belum melaksanakan hasil pendidikan dan penelitian yang dapat dimanfaatkan langsung oleh masyarakat. Sementara kinerja tenaga kependidikan hampir merata dalam setiap aspeknya, yaitu pada kategori sedang.

\section{Tingkat Loyalitas Dosen dan Tenaga Kependidikan}

Data tingkat loyalitas dosen dan tenaga kependidikan dapat dilihat pada tabel berikut.

Tabel 5

Persentase Loyalitas Dosen dan Tenaga Kependidikan

\begin{tabular}{|l|l|l|c|}
\hline \multicolumn{1}{|c|}{ Responden } & \multicolumn{3}{c|}{ Frekuensi Kinerja } \\
\hline & Tinggi (\%) & Sedang (\%) & Rendah (\%) \\
\hline Dosen & $40(83,33 \%)$ & $8(16,67 \%)$ & - \\
\hline Tenaga Kependidikan & $22(84,62 \%)$ & $4(15,38 \%)$ & - \\
\hline \multicolumn{1}{|c|}{ TOTAL } & $\mathbf{6 2}(\mathbf{8 3 , 7 8 \% )}$ & $\mathbf{1 2}(\mathbf{1 6 , 2 2} \%)$ & - \\
\hline
\end{tabular}




\section{LOYALITAS DOSEN DAN TENAGA KEPENDIDIKAN}

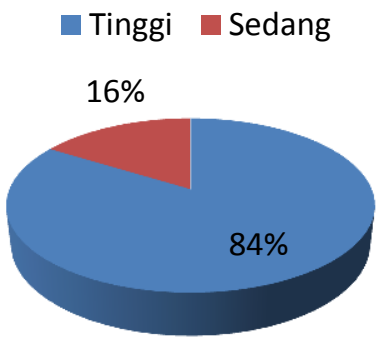

\section{Gambar 5}

\section{Diagram Serabi Variabel Loyalitas Dosen dan Tenaga Kependidikan}

Berdasarkan tabel 8 di atas, dilihat dari 48 orang dosen yang menjadi responden penelitian ini, dapat diketahui bahwa rata-rata tingkat loyalitas, berada pada kategori tinggi (83,33\%), demikian juga untuk tenaga kependidikan rata-rata berada pada kategori tinggi (84,62\%). Dilihat secara keseluruhan tingkat loyalitas dosen dan tenaga kependidikan berada pada kategori tinggi (mean dengan interval 71 - 90) sebanyak 83,78\%. Jika dibandingkan dengan hasil perhitungan SPSS diperoleh mean kinerja sebesar 76,0135.

\section{Pengaruh Kepuasan Pengelolaan SDM (X) Terhadap Kinerja Dosen dan} Tenaga Kependidikan ( $\left.Y_{1}\right)$

Hasil analisis dari kepuasan Pengelolaan SDM (X) terhadap Kinerja Dosen dan Tenaga Kependidikan (Y) termuat dalam table berikut ini.

Tabel 6

Korelasi Kepuasan Pengelolaan SDM (X) Terhadap Kinerja Dosen dan Tenaga Kependidikan $\left(\mathrm{Y}_{1}\right)$

\begin{tabular}{|ll|r|r|}
\hline & & $\mathrm{Y}_{1}$ & \multicolumn{1}{|c|}{ X } \\
\hline Pearson & Y1 & 1,000 &, 291 \\
Correlation & &, 291 & 1,000 \\
& X & $\cdot$ &, 006 \\
Sig. (1-tailed) & Y1 &, 006 & $\cdot$ \\
& X & 74 & 74 \\
N & Y1 & 74 & 74 \\
& X & & \\
& & &
\end{tabular}


42 | TAZKIR: Jurnal Penelitian Ilmu-ilmu Sosial dan Keislaman

Vol.03 No. 1 Juni 2017

Tabel 7

Hasil Analisis Korelasi Kepuasan Pengelolaan SDM (X) Terhadap Kinerja Dosen dan Tenaga Kependidikan ( $\left.\mathrm{Y}_{1}\right)$

\begin{tabular}{|c|c|c|c|c|c|c|c|c|c|}
\hline \multirow{2}{*}{$\begin{array}{c}\text { Mode } \\
1\end{array}$} & \multirow{2}{*}{$\begin{array}{c}\mathrm{R} \\
\mathrm{R} \\
\text { Square } \\
\text { Chang } \\
\mathrm{e}\end{array}$} & \multirow{2}{*}{$\begin{array}{c}\mathrm{R} \\
\text { Square } \\
\text { F } \\
\text { Chang } \\
\text { e }\end{array}$} & \multirow{2}{*}{$\begin{array}{l}\text { Adjuste } \\
\text { d R } \\
\text { Square } \\
\text { df1 }\end{array}$} & \multirow{2}{*}{$\begin{array}{c}\text { Std. } \\
\text { Error of } \\
\text { the } \\
\text { Estimate } \\
\text { df2 }\end{array}$} & \multicolumn{5}{|c|}{ Change Statistics } \\
\hline & & & & & $\begin{array}{l}\text { Sig. F } \\
\text { Chang } \\
\text { e }\end{array}$ & $\begin{array}{c}\mathrm{R} \\
\text { Square } \\
\text { Chang } \\
\mathrm{e} \\
\end{array}$ & $\begin{array}{c}\text { F } \\
\text { Chang } \\
\mathrm{e}\end{array}$ & $\begin{array}{c}\mathrm{df} \\
1\end{array}$ & df2 \\
\hline 1 & ,291(a) & 085 & ,072 & 8,19214 & ,085 & 6,660 & 1 & 72 & ,012 \\
\hline
\end{tabular}

a Predictors: (Constant), $\mathrm{X}$

b Dependent Variable: $Y 1$

Tabel 8

Hasil Ringkasan Anava untuk Uji Signifikansi

ANOVA(b)

\begin{tabular}{|ll|r|r|r|r|r|}
\hline \multicolumn{2}{|l|}{$\begin{array}{l}\text { Mode } \\
1\end{array}$} & \multicolumn{1}{|c|}{$\begin{array}{c}\text { Sum of } \\
\text { Squares }\end{array}$} & Df & \multicolumn{1}{c|}{$\begin{array}{l}\text { Sean } \\
\text { Square }\end{array}$} & \multicolumn{1}{c|}{ F } & Sig. \\
\hline 1 & Regression & 446,979 & 1 & 446,979 & 6,660 &, $012(\mathrm{a})$ \\
& Residual & 4832,008 & 72 & 67,111 & & \\
& Total & 5278,986 & 73 & & & \\
\hline
\end{tabular}

a Predictors: (Constant), $\mathrm{X}$

b Dependent Variable: $Y 1$

Tabel 9

Hasil Analisis Regresi X terhadap $\mathrm{Y}_{1}$

Coefficients(a)

\begin{tabular}{|c|c|c|c|c|c|c|c|c|}
\hline \multirow[t]{2}{*}{ el $\quad$ Mod } & \multicolumn{2}{|c|}{$\begin{array}{c}\text { Unstandardized } \\
\text { Coefficients }\end{array}$} & \multirow{2}{*}{$\begin{array}{c}\begin{array}{c}\text { Standardize } \\
\mathrm{d}\end{array} \\
\text { Coefficients } \\
\text { Beta }\end{array}$} & \multirow{2}{*}{$\begin{array}{c}\mathrm{t} \\
\text { Zero- } \\
\text { order }\end{array}$} & \multirow{2}{*}{$\begin{array}{l}\text { Sig. } \\
\text { Parti } \\
\text { al }\end{array}$} & \multicolumn{3}{|c|}{ Correlations } \\
\hline & B & $\begin{array}{l}\text { Std. } \\
\text { Error }\end{array}$ & & & & Part & B & $\begin{array}{l}\text { Std. } \\
\text { Error }\end{array}$ \\
\hline 1 (Constant) & $\begin{array}{r}67,80 \\
6\end{array}$ & 4,436 & & 15,287 & ,000 & & & \\
\hline$X$ & ,212 & ,082 & 291 & 2,581 & ,012 & 291 & 291 & 291 \\
\hline
\end{tabular}

a Dependent Variable: Y1

Berdasarkan tabel 6 bahwa besarnya pengaruh variabel kepuasan pengelolaan SDM $(\mathrm{X})$ terhadap kinerja dosen dan pegawai (Y1) yang dihitung 
koefisien korelasi adalah 0,291 atau $\left(\mathrm{r} \times \mathrm{r}_{1}=0,291\right)$. Hal ini menunjukkan pengaruh yang lemah di antara kepuasan dengan kinerja.

Selanjutnya dilihat dari tabel 8 dari uji anova atau Ftes ternyata diperoleh Fhitung sebesar 6,660 dengan tingkat signifikansi 0,012. Namun, umumnya tingkat signifikansi yang digunakan dalam ilmu sosial adalah 0,05, sementara tingkat signifikansi yang digunakan 0,012 sehingga hasilnya lebih rendah tingkat ssignifikansinya.

Dari tabel 12 menggambarkan bahwa persamaan regresi sebagai berikut: $\hat{Y}=a+b_{1} X_{1}=67,80+0,291 X_{1}$

Konstanta sebesar 67,80 menyatakan bahwa jika tidak ada kenaikan nilai dari variabel kepuasan (X), maka nilai kinerja dosen dan tenaga kependidikan (Y) adalah 67,80. Koefisien regresi sebesar 0,291 menyatakan bahwa setiap penambahan satu skor atau nilai kepuasan akan memberikan peningkatan skor sebesar 0,291.

Uji t dilakukan untuk menguji signifikansi konstanta dan variabel dependen (kepuasan pengelolaan SDM). Kriteria uji koefisien regresi dari variabel kepuasan terhadap kinerja dosen dan tenaga kependidikan sebagai berikut:

Jika nilai thitung $>$ nilai tabel, maka Ho ditolak artinya koefisien regresi signifikan. Sebaliknya jika thitung < nilai ttabel, maka Ho diterima artinya koefisien regresi tidak signifikan.

Berdasarkan hasil perhitungan pada tabel 9 menunjukkan bahwa $\mathrm{t}$ hitung $=$ 2,581 sedangkan $t_{\text {tabel }}=1,663$. Jika thitung $(2,581)>$ tabel $(1,663)$, maka Hoditolak atau $\mathrm{H}_{\mathrm{a}}$ diterima. Hal ini berarti bahwa hipotesis alternatif yang berbunyi: Kepuasan terhadap pengelolaan SDM berpengaruh positif terhadap kinerja dosen dan tenaga kependidikan IAIN Padangsidimpuan, diterima. Jadi terdapat korelasi variabel kepuasan pengelolaan SDM terhadap kinerja dosen dan tenaga kependidikan yang signifikan.

Selanjutnya berdasarkan analisis tabel 7 terdapat $R$ square (koefisien diterminasi) sebesar 0,085 merupakan hasil pengkuadratan dari koefisien korelasi 0,291 atau 0,2912. Dengan demikian kontribusi variabel kepuasan terhadap pengelolaan SDM hanya $8,50 \%$ sedangkan sisanya $91,50 \%$ dapat dijelaskan oleh sebab-sebab yang lain.

\section{Pengaruh Kepuasan Pengelolaan SDM (X) Terhadap Loyalitas Dosen dan Tenaga Kependidikan $\left(Y_{2}\right)$}


44 | TAZKIR: Jurnal Penelitian Ilmu-ilmu Sosial dan Keislaman

Vol.03 No. 1 Juni 2017

Untuk korelasi antara Pengelolaan SDM dengan loyalitas Dosen dan Tenaga Kependidikan dapat dilihat dalam tabel berikut:

Tabel 10

Korelasi Kepuasan Pengelolaan SDM (X)

Terhadap Loyalitas Dosen dan Tenaga Kependidikan $\left(Y_{2}\right)$

\begin{tabular}{|ll|r|r|}
\hline & & \multicolumn{1}{|c|}{$\mathrm{Y}_{2}$} & \multicolumn{2}{|c|}{$\mathrm{X}$} \\
\hline Pearson & $\mathrm{Y} 2$ & 1,000 &, 282 \\
Correlation & &, 282 & 1,000 \\
& $\mathrm{X}$ &. &, 007 \\
Sig. (1-tailed) & $\mathrm{Y} 2$ &, 007 & $\cdot$ \\
& $\mathrm{X}$ & 74 & 74 \\
$\mathrm{~N}$ & $\mathrm{Y} 2$ & 74 & 74 \\
\hline
\end{tabular}

Tabel 11

Hasil Analisis Korelasi Kepuasan Pengelolaan SDM (X)

Terhadap Loyalitas Dosen dan Tenaga Kependidikan $\left(\mathrm{Y}_{2}\right)$

\begin{tabular}{|c|c|c|c|c|c|c|c|c|c|}
\hline $\begin{array}{l}\text { Mode } \\
1\end{array}$ & $\mathrm{R}$ & $\begin{array}{c}\mathrm{R} \\
\text { Square }\end{array}$ & $\begin{array}{l}\text { Adjuste } \\
\text { d R } \\
\text { Square }\end{array}$ & $\begin{array}{l}\text { Std. Error } \\
\text { of the } \\
\text { Estimate }\end{array}$ & & Chang & Statisti & & \\
\hline & $\begin{array}{c}\mathrm{R} \\
\text { Square } \\
\text { Chang } \\
\mathrm{e}\end{array}$ & $\begin{array}{c}\text { F } \\
\text { Chang } \\
\text { e }\end{array}$ & df1 & df2 & $\begin{array}{l}\text { Sig. F } \\
\text { Chang } \\
\text { e }\end{array}$ & $\begin{array}{c}\mathrm{R} \\
\text { Square } \\
\text { Chang } \\
\mathrm{e}\end{array}$ & $\begin{array}{c}\text { F } \\
\text { Chang } \\
\text { e }\end{array}$ & df1 & df2 \\
\hline 1 & ,282(a) & 080 & 067 & 5,48161 & ,080 & 6,241 & 1 & 72 & ,015 \\
\hline
\end{tabular}

Tabel 12

Hasil Ringkasan Anava Untuk Uji Signifikansi

ANOVA(b)

\begin{tabular}{|ll|r|r|r|r|r|}
\hline \begin{tabular}{ll|r|r|r|} 
M \\
od
\end{tabular} & & \multicolumn{1}{c|}{$\begin{array}{l}\text { Sum of } \\
\text { el }\end{array}$} & & & & \\
\hline 1 & Regression & 187,525 & 1 & 187,525 & 6,241 & Sig. \\
\hline & Residual & 2163,461 & 72 & 30,048 & & \\
& Total & 2350,986 & 73 & & & \\
\hline
\end{tabular}


Tabel 13

Hasil Analisis Regresi X Terhadap $Y_{2}$

Coefficients(a)

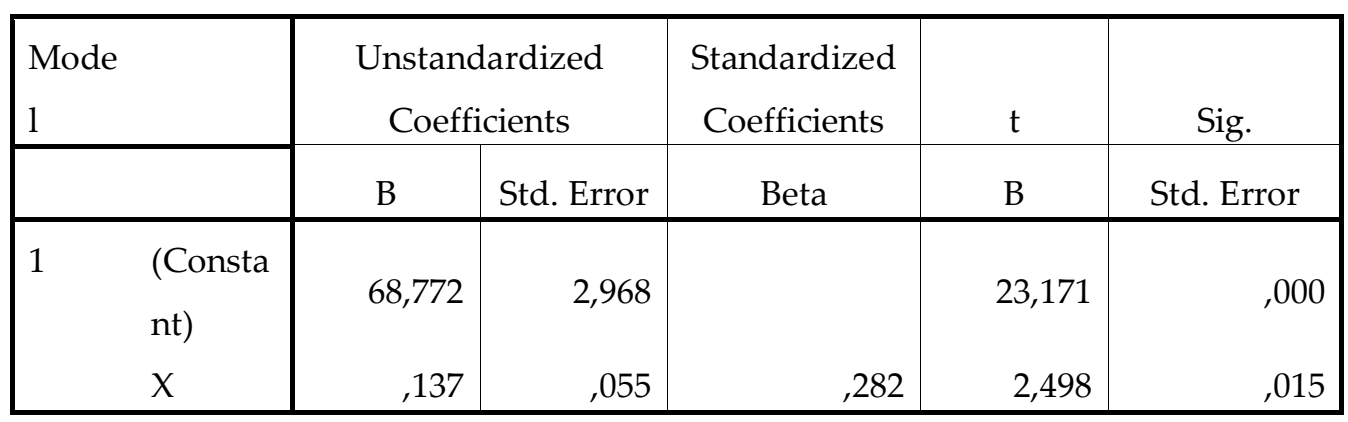

Berdasarkan tabel 10 bahwa besarnya pengaruh variabel kepuasan pengelolaan SDM $(\mathrm{X})$ terhadap kinerja dosen dan pegawai (Y1) yang dihitung koefisien korelasi adalah 0,282 atau $(r \times y 1=0,282)$. Hal ini menunjukkan pengaruh yang lemah di antara kepuasan terhadap pengelolaan SDM dengan loyalitas dosen dan tenaga kependidikan.

Selanjutnya dilihat dari tabel 12 dari uji anova atau Ftes ternyata diperoleh Fhitung sebesar 6,241 dengan tingkat signifikansi 0,015. Dari tabel 16 menggambarkan bahwa persamaan regresi sebagai berikut:

$$
\hat{Y}=a+b_{1} X_{1}=68,772+0,282 X_{1}
$$

Konstanta sebesar 68,772 menyatakan bahwa jika tidak ada kenaikan nilai dari variabel kepuasan $(X)$, maka nilai loyalitas dosen dan tenaga kependidikan (Y) adalah 68,772. Koefisien regresi sebesar 0,282 menyatakan bahwa setiap penambahan satu skor atau nilai kepuasan akan memberikan peningkatan skor sebesar 0,282.

Uji $\mathrm{t}$ dilakukan untuk menguji signifikansi konstanta dan variabel dependen (kepuasan pengelolaan SDM). Kriteria uji koefisien regresi dari variabel kepuasan terhadap loyalitas dosen dan tenaga kependidikan sebagai berikut: jika nilai thitung > nilai tabel, maka Ho ditolak artinya koefisien regresi signifikan. Sebaliknya jika thitung < nilai tabel, maka Ho diterima artinya koefisien regresi tidak signifikan.

Berdasarkan hasil perhitungan pada tabel 13 menunjukkan bahwa $t$ hitung $=$ 2,498 sedangkan tabel $=1,663$. Jika thitung $(2,498)>$ tabel $(1,663)$, maka Ho ditolak atau $\mathrm{H}_{\text {a }}$ diterima. Hal ini berarti bahwa hipotesis alternatif yang berbunyi: Kepuasan terhadap pengelolaan SDM berpengaruh positif terhadap loyalitas dosen dan 
46 | TAZKIR: Jurnal Penelitian Ilmu-ilmu Sosial dan Keislaman

Vol.03 No. 1 Juni 2017

tenaga kependidikan IAIN Padangsidimpuan, diterima. Jadi terdapat korelasi variabel kepuasan pengelolaan SDM terhadap loyalitas dosen dan tenaga kependidikan yang signifikan.

Selanjutnya berdasarkan analisis tabel 11 terdapat $\mathrm{R}$ square (koefisien diterminasi) sebesar 0,080 merupakan hasil pengkuadratan dari koefisien korelasi 0,282 atau 0,282 . Dengan demikian kontribusi variabel kepuasan terhadap pengelolaan SDM hanya $8 \%$ sedangkan sisanya $92 \%$ dapat dijelaskan oleh sebab-sebab yang lain.

\section{KESIMPULAN}

Dari hasil penelitian ini dapat ditarik kesimpulan sebagai berikut:

1. Tingkat kepuasan dosen dan tenaga kependidikan terhadap pengelolaan sumber daya manusia IAIN Padangsidimpuan berada pada kategori sedang yaitu 52,70\%, dengan nilai rata-rata kepuasan sebesar 52,7973.

2. Tingkat kinerja dosen dan tenaga kependidikan terhadap pengelolaan sumber daya manusia IAIN Padangsidimpuan berada pada kategori sedang yaitu $81,08 \%$, dengan nilai rata-rata kinerja sebesar 78,9865.

3. Tingkat loyalitas dosen dan tenaga kependidikan terhadap pengelolaan sumber daya manusia IAIN Padangsidimpuan berada pada kategori tinggi yaitu 83,78\%, dengan nilai rata-rata loyalitas sebesar 76,0135.

4. Pengaruh kepuasan pengelolaan sumber daya manusia terhadap kinerja dosen dan tenaga kependidikan IAIN Padangsidimpuan sebesar 0,291. Angka koefisien korelasi ini menunjukkan lemahnya pengaruh kepuasan pengelolaan sumber daya manusia terhadap kinerja dosen dan tenaga kependidikan IAIN Padangsidimpuan.

5. Pengaruh kepuasan pengelolaan sumber daya manusia terhadap loyalitas dosen dan tenaga kependidikan IAIN Padangsidimpuan sebesar 0,282. Angka koefisien korelasi ini menunjukkan lemahnya pengaruh kepuasan pengelolaan sumber daya manusia terhadap loyalitas dosen dan tenaga kependidikan IAIN Padangsidimpuan. 
Pengaruh Kepuasan Pengelolaan..... ASNAH | 47

\section{DAFTAR PUSTAKA}

A. Usmara. Motivasi Kerja: Proses, Teori dan Praktik. Yogyakarta: Amara Books, 2006.

Daniel C Fieldman dan Arnold. Managing Individual and Group Behavior in Education. Singapore: Mc Graw Hill Book Co., 2013.

Lyman W. Porter. Managerial Attitudes and Performance. Texas: Business Publication, 1996.

Moh. As'ad. Psikologi Industri. Yogyakarta: Liberty, 2004.

Sedarmayanti. Sumber Daya Manusia dan Produktivitas Kerja. Bandung: Mandar Maju, 2011. 
48 | TAZKIR: Jurnal Penelitian Ilmu-ilmu Sosial dan Keislaman Vol.03 No. 1 Juni 2017

Pertimbangan Hukum Hakim dalam Putusan Tindak Pidana Asusila Anak di Bawah Umur

Rahmat Efendy Al Amin Siregar 